\title{
Implementation of Islamic Boarding School Rules in Establishing Student Discipline in Jagad 'Alimusirry Islamic Student Boarding Schools
}

\author{
Z Darojat \\ Civic Education, Faculty of Social Sciences and Law, Surabaya State University, Indonesia \\ Student Jagad 'Alimussirry Boarding School Surabaya, Indonesia \\ zakiyatud@gmail.com
}

\begin{abstract}
The current of globalization has led to competition in the world of education, so education is needed to make young people who are dignified, become responsible and democratic citizens. Islamic boarding schools as one of the institutions in non-formal education are tasked with forming the character and personality of the religious people to become a glorious and highly disciplined person. This research was conducted using a qualitative approach with a qualitative descriptive design. The method is used to find out how to implement the order in the Jagad 'Alimussirry Islamic boarding school. This research showed that the formation of discipline through the order given so that students are able to become disciplined individuals by obeying the rules that have been made by Islamic boarding schools. Kyai (teacher) and also islamic boarding houses have an important role in the process of implementing the order.
\end{abstract}

Keywords: rules, student, islamic boarding school.

\section{INTRODUCTION}

Non-formal education in the Republic of Indonesia Law No. 20 of 2003 concerning the National Education System, states that the definition of non-formal education is a pathway to education outside formal education that can be carried out in a structured and tiered manner. One of the non-formal educational institutions in Indonesia is Islamic boarding schools. Islamic boarding schools are the oldest educational institutions in Indonesia, which have given birth to many: ulama' (Teacher) [1]. Islamic boarding schools are tasked with forming the character and personality of the student to have a noble, noble, and highly disciplined personality. This is supported by the many rules and sanctions contained in boarding schools.

Discipline education of student is the most important element and the most effective means in the education process in boarding schools [2]. The formation of student discipline can be done through activities that are in the environment of Islamic boarding schools. Discipline is the power instilled by educators to instill in the soul about the behavior in the student's personality and the form of habits in them, submit and obey the truth in the rules that are in accordance with the principle of real education which is the core that is carried out in each activity school [3]. Formation of discipline through teaching and learning activities that is at the same time with the integration of boarding school boarding order to student

Rules are a guideline for Islamic boarding schools to create a safe, comfortable and orderly atmosphere so that learning is protected from deviant actions. Enforcement of discipline in boarding schools is very important. This is because by implementing the order in boarding schools can reduce the negative actions of the student such as late dating or ditching during teaching and learning activities. By enforcing strict discipline through the implementation of discipline, students can become accustomed to being disciplined so that violations in Islamic boarding schools can be reduced. Therefore, the lodge must carry out the order consistently from 
both the teacher and the student so as to improve the quality of the student's behavior.

Based on observations in the Jagad 'Alimussirry Islamic boarding school in Surabaya, it shows that there needs to be an increase because there are still many student who violate the cottage rules both in terms of study or order in daily life while in boarding schools.

The fact that happened before the rule was related to the prohibition for those who did not take part in teaching and learning activities in the Jagad 'Alimussirry Islamic boarding school showed that many student often did not attend the teaching and learning activities. This is known by the absence of attendance signatures written by each student. With the many absences of absenteeism from each student, it was shown that many students did not take part in the study in Islamic boarding schools, as well as the number of students who did not fulfill their obligations in Islamic boarding schools such as not carrying out daily pickets at the hut.

Based on the description described above, the problem raised in this research is how the efforts to form the discipline of student through the implementation of the Islamic boarding school discipline and the obstacles experienced by the cottage in shaping the discipline of student through the implementation of rules in the Islamic Boarding School Students 'Alimussirry Surabaya. The formulation of the problem in this study are as follows: 1) how are the efforts made by Islamic boarding schools in shaping the discipline of student through the implementation of cottage rules? and, 2) what obstacles are experienced in the process of implementing cottage rules in shaping the discipline of student?

\section{METHOD}

This research was conducted using a qualitative approach with a qualitative descriptive design. This method is used to find out how to implement the order in the Jagad 'Alimussirry Islamic boarding school. In the process of retrieving data in this study using data collection techniques with observation, interviews, and documentation. Observation is done by participatory observation so that researchers know firsthand the implementation of the existing order. The interview was carried out to the management to provide an explanation regarding the implementation of orderly Jagad's 'Alimussirry. The documentation in this study was obtained from data owned Jagad's cottage im Alimussirry about data on the participation of student in the learning process carried out.

\section{DISCUSSION}

Implementation of the Code of Conduct in shaping the discipline of student in the Islamic Boarding School ad Alimussirry A teacher not only transfers knowledge, but also socializes values and norms. This combination will strengthen the building of students' knowledge, morals, and personality in welcoming the future. To achieve the discipline of student there are several elements of discipline so that they can be formed according to the desired goals.

The way to educate them must have three elements, namely: 1) Regulation, is a pattern that is set for behavior that aims to equip children with agreed behavioral guidelines in certain situations [4]. 2) Penalties or Sanctions, penalties can function to avoid repetition of unwanted actions, educate, motivate to avoid behavior that is not accepted. Punishment is an educational tool whose variety varies. There are educational tools that are very important for the implementation of education, namely: habituation, orders, prohibitions, punishments and recommendations [5] and 3) Awards, Awards in Islam are usually referred to as reward, as the word of Allah SWT in the verse 11 means "Except those who are patient (towards disaster) and do good deeds, they receive great forgiveness and mercy.

Based on findings in the field, efforts to establish student discipline through the implementation of Islamic boarding school discipline are carried out with the following activities: 1) Regulations, namely the holding of absences in the Koran recitation activities. Attendance is given every teaching and learning process. Attendance is given by each carrier responsible for missing each subject. The attendance will be recorded to do the calculation of the number of times each student does not attend each study course. If it exceeds the predetermined limit, the student will be subject to sanctions that have been determined by the Jagad 'Alimussirry boarding school. 2) Advice from caregivers to comply with the rules of each process of the Koran and also advice from the boarders of the boarding school for the student. This is expected to benefit the discipline of the student so that the student will slowly understand 
the intent and purpose of the rules being implemented. 3) Give strict sanctions if it violates the rules of the boarding school. Giving sanctions is given to discipline students to always take subject studies every day. Sanctions were given to students who violated the rules in the Jagad 'Alimussirry Islamic boarding school, which did not take eight study courses for nonformal undergraduates and four times did not study courses for non-formal S2. The existence of this sanction can be said to be quite successful because the level of participation of student in the course study activities has declined. This is evidenced by the following Table I:

Table. I Data of S1 and S2 students exceeding the limit of not taking study Non-Formal Education of Islamic Student Ponpes pes Alimussirry Surabaya

\begin{tabular}{|c|c|c|c|}
\hline No & $\begin{array}{c}\text { Educational } \\
\text { Level }\end{array}$ & $\begin{array}{l}\text { Number of } \\
\text { Students }\end{array}$ & $\begin{array}{l}\text { Student Did Not } \\
\text { Participate in } \\
\text { Study }\end{array}$ \\
\hline 1 & S1 & 108 & 5 \\
\hline 2 & S2 & 24 & 3 \\
\hline
\end{tabular}

In Table I it shows that the discipline of student in taking education studies in either non-formal S1 or S2 has gone well. Given the rules in participating in the study of education at the Jagad 'Alimussirry Islamic Boarding School, it would seem that the participation of student in taking part in the study showed a small number.

In addition to the rules for taking study courses, there are still rules regarding life in Islamic boarding schools, namely the rules for carrying out cleaning pickets, prayer prayers and picket guarding the lodge. Regarding these rules, there are sanctions that are also given so that the order is carried out by all students. However, not all of these rules are given

Real sanctions but given moral sanctions such as the advice of violators of these rules. So that there needs to be self-awareness in the form of self-discipline so that the implementation of the rules in the boarding school run well. Discipline is control, more importantly is the principle that discipline is an exercise in self-control [6].
Obstacles to Implementation of Rules of Conduct in Forming Student Discipline

Obstacles experienced in shaping the discipline of student through the implementation of the Islamic boarding school discipline are students, there are still many activities that are owned by the student in addition to attending education studies and daily rules while in boarding schools. This is evidenced by the fact that there are still student who often do not take education studies even though they do not show a large number and there are still many student who do not carry out obligations such as not picking up, not carrying out the priests' prayers and not guarding the security of the lodge. Such activities are due to the participation of students who are also students who also participate in organizations on campus. They did not study because they had activities in their organization.

It is not only a matter of the participation of students who are also students in organizational activities. However, there are also not a few students who work so that they cannot take full study of education and picket huts. The work they have requires a lot of time so that they cannot follow the study and pick up the cottage.

\section{CONCLUSION}

Implementation of Islamic Boarding School Rules in Establishing Student Discipline efforts to form student discipline through the implementation of Islamic boarding school discipline are carried out with the following activities: 1) Regulations namely the absence of recitation activities, 2) Advice from caregivers to comply with the rules of each process and also advice from board management in daily life in Islamic boarding schools, 3) Give strict sanctions when violating the rules of the Islamic boarding school. Obstacles experienced in shaping the discipline of student through the implementation of Islamic boarding school rules are students, there are still many activities which is owned 
by student besides attending education studies in Islamic boarding schools and student who work so that they cannot always take education studies.

\section{REFERENCES}

[1] I. Syafe'I, "Pondok Pesantren: Lembaga Pendidikan Pembentukan Karakter", Jurnal Pendidikan Islam, Vol. 8, 2017.

[2] S. A. Redho, "Manajemen Pendidikan Kedisiplinan Student di Pondok Pesantren",
Universitas Islam Negeri Maulana Malik Ibrahim, 2015.

[3] M. Yunus, "At Tarbiyah wa Ta'lim, Juz II", Ponorogo: Darussalam Pers, 1991.

[4] E. B. Hurlock, "Perkembangan Anak", Jakarta: Erlangga.

[5] N. Purwanto, "Ilmu Pendidikan Teoritis dan Praktis”, Bandung: Remaja Rosda Karya, 1993.

[6] K. S. Benhart, "Dicipline and Child Guidance", Toronto: McGraw Hill Inc, 1964. 